\title{
Godiva Rim Member-A New Stratigraphic Unit of the Green River Formation in Southwest Wyoming and Northwest Colorado
}

U.S. GEOLOGICAL SURVEY PROFESSIONAL PAPER 1506-C

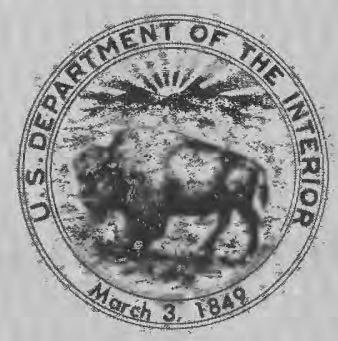




\section{AVAILABILITY OF BOOKS AND MAPS OF THE U.S. GEOLOGICAL SURVEY}

Instructions on ordering publications of the U.S. Geological Survey, along with prices of the last offerings, are given in the current-year issues of the monthly catalog "New Publications of the U.S. Geological Survey." Prices of available U.S. Geological Survey publications released prior to the current year are listed in the most recent annual "Price and Availability List." Publications that are listed in various U.S. Geological Survey catalogs (see back inside cover) but not listed in the most recent annual "Price and Availability List" are no longer available.

Prices of reports released to the open files are given in the listing "U.S. Geological Survey Open-File Reports," updated monthly, which is for sale in microfiche from the U.S. Geological Survey, Books and Open-File Reports Section, Federal Center, Box 25425, Denver, CO 80225. Reports released through the NTIS may be obtained by writing to the National Technical Information Service, U.S. Department of Commerce, Springfield, VA 22161; please include NTIS report number with inquiry.

Order U.S. Geological Survey publications by mail or over the counter from the offices given below.

\section{BY MAIL}

\section{Books}

Professional Papers, Bulletins, Water-Supply Papers, Techniques of Water-Resources Investigations, Circulars, publications of general interest (such as leaflets, pamphlets, booklets), single copies of Earthquakes \& Volcanoes, Preliminary Determination of Epicenters, and some miscellaneous reports, including some of the foregoing series that have gone out of print at the Superintendent of Documents, are obtainable by mail from

U.S. Geological Survey, Books and Open-File Reports Federal Center, Box 25425 Denver, CO 80225

Subscriptions to periodicals (Earthquakes \& Volcanoes and Preliminary Determination of Epicenters) can be obtained ONLY from the

\section{Superintendent of Documents \\ Government Printing Office \\ Washington, D.C. 20402}

(Check or money order must be payable to Superintendent of Documents.)

\section{Maps}

For maps, address mail orders to

\section{U.S. Geological Survey, Map Distribution \\ Federal Center, Box 25286 \\ Denver, CO 80225}

Residents of Alaska may order maps from

Alaska Distribution Section, U.S. Geological Survey, New Federal Building - Box 12 101 Twelfth Ave., Fairbanks, AK 99701

\section{OVER THE COUNTER}

\section{Books}

Books of the U.S. Geological Survey are available over the counter at the following Geological Survey Public Inquiries Offices, all of which are authorized agents of the Superintendent of Documents:

- WASHINGTON, D.C.--Main Interior Bldg., 2600 corridor, 18 th and C Sts., NW.

- DENVER, Colorado--Federal Bldg., Rm. 169, 1961 Stout St.

- LOS ANGELES, California--Federal Pldg., Rm. 7638, 300 N. Los Angeles St.

- MENLO PARK, California--Bldg. 3 (Stop 533), Rm. 3128, 345 Middlefield Rd.

- RESTON, Virginia--503 National Center, Rm. 1C402, 12201

Sunrise Valley Dr.

- SALT LAKE CITY, Utah--Federal Bldg., Rm. 8105, 125 South State St.

- SAN FRANCISCO, California--Customhouse, Rm. 504, 555 Battery St.

- SPOKANE, Washington--U.S. Courthouse, Rm. 678, West 920 Riverside Ave.

- ANCHORAGE, Alaska--Rm. 101, 4230 University Dr.

- ANCHORAGE, Alaska--Federal Bldg, Rm. E-146, 701 C St.

\section{Maps}

Maps may be purchased over the counter at the U.S. Geological Survey offices where books are sold (all addresses in above list) and at the following Geological Survey offices:

- ROLLA, Missouri--1400 Independence Rd.

- DENVER, Colorado--Map Distribution, Bldg. 810, Federal Center

- FAIRBANKS, Alaska--New Federal Bldg., 101 Twelfth Ave. 
GODIVA RIM MEMBER-A NEW STRATIGRAPHIC UNIT OF THE GREEN RIVER FORMATION IN SOUTHWEST WYOMING AND NORTHWEST COLORADO 


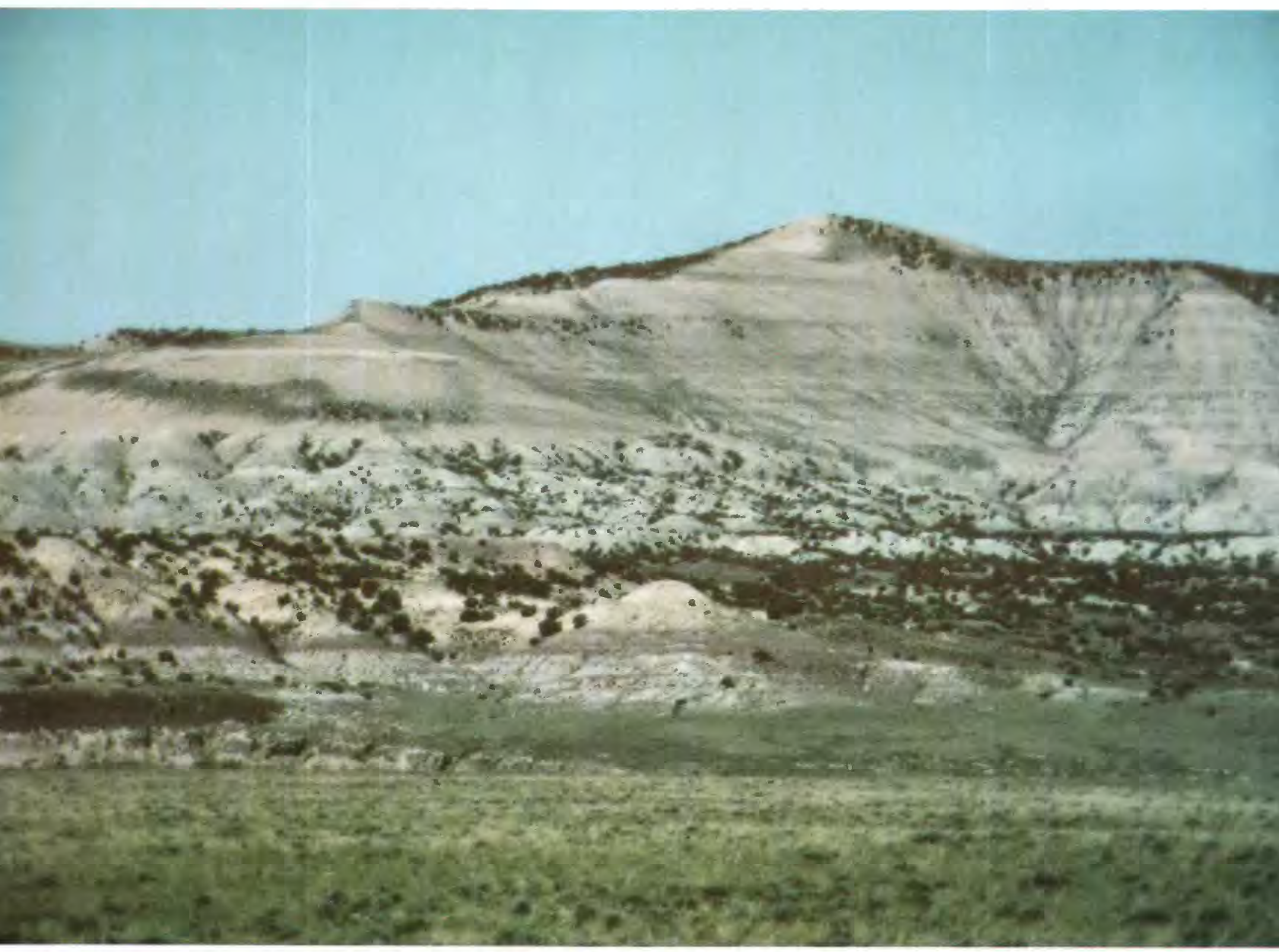

Outcrops of the LaClede Bed of the Laney Member (weathers tan) and Godiva Rim Member (weathers gray) of the Green River Formation and Cathedral Bluffs Tongue of the Wasatch Formation (weathers red, tan, and gray) on the west side of the Little Snake River in the Sand Wash basin. View is west toward The Nipple. 


\section{Godiva Rim Member-A New Stratigraphic Unit of the Green River Formation in Southwest Wyoming and Northwest Colorado}

$B y$ HENRY W. ROEHLER

GEOLOGY OF THE EOCENE WASATCH, GREEN RIVER, AND BRIDGER (WASHAKIE) FORMATIONS, GREATER GREEN RIVER BASIN, WYOMING, UTAH, AND COLORADO

U.S. GEOLOGICAL SURVEY PROFESSIONAL PAPER 1506-C

Description of lithofacies of lacustrine and mudflat origin along the eastern margins of Eocene Lake Gosiute in the Washakie and Sand Wash basins

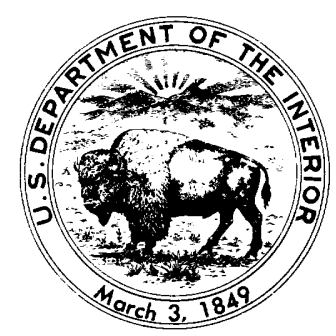




\title{
U.S. DEPARTMENT OF THE INTERIOR
}

\author{
MANUEL LUJAN, JR., Secretary
}

\section{U.S. GEOLOGICAL SURVEY}

\author{
Dallas L. Peck, Director
}

\begin{abstract}
Any use of trade, product, or firm names in this publication is for descriptive purposes only and does not imply endorsement by the U.S. Government
\end{abstract}

\section{Library of Congress Cataloging in Publication Data}

Roehler, Henry W.

Godiva Rim Member-a new stratigraphic unit of the Green River Formation in southwest Wyoming and northwest Colorado / by Henry W. Roehler.

p. cm. - (Geology of the Eocene Wasatch, Green River, and Bridger (Washakie) formations, greater Green River Basin, Wyoming, Utah, and Colorado) (U.S Geological Survey professional paper ; 1506-C)

"Description of lithofacies of lacustrine and mudflat origin along the eastern margins of Eocene Lake Gosiute in the Washakie and Sand Wash basins."

Includes bibliographical references.

Supt. of Does. no.: I 19.16:1506-C

1. Geology, Stratigraphic-Eocene. 2. Geology-Wyoming. 3. Geology-Colorado. 4. Green River Formation. I. Title. II. Series. III. Series: U.S. Geological Survey professional paper ; 1506-C. QE692.2.R6 1991

$551.7^{\prime} 84^{\prime} 0978785-\mathrm{dc} 20$

For sale by the Books and Open-File Reports Section, U.S. Geological Survey, Federal Center, Box 25425, Denver, CO 80225 


\section{CONTENTS}

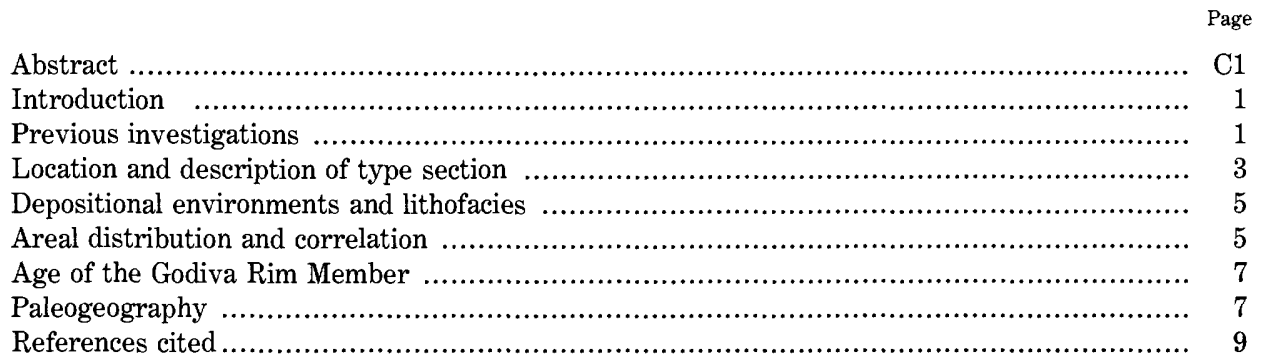

\section{ILLUSTRATIONS}

FIgURE 1. Map showing location of greater Green River basin and the approximate Eocene areal distribution of the Godiva Rim Member

2. Photograph of outcrops of the Godiva Rim Member and overlying and underlying rocks on Godiva Rim

3. Generalized cross section of Eocene rocks in greater Green River basin

4. Geologic map of the Godiva Rim area

5. Photograph of the type section of the Godiva Rim Member.....

6. Columnar section of the type Godiva Rim Member and adjacent rocks

7. Cross sections showing the stratigraphic relationships of the Godiva Rim Member in the Washakie and Sand Wash basins....

8. Photograph showing outcrops of the buff marker bed and adjacent oil shale beds on Kinney Rim in Washakie basin

9. Photograph showing outcrops of the Godiva Rim Member and adjacent rocks near The Nipple in Sand Wash basin

10. Cross section showing probable connections of Lake Gosiute with Lake Uinta 



\title{
GODIVA RIM MEMBER-A NEW STRATIGRAPHIC UNIT OF THE GREEN RIVER FORMATION IN SOUTHWEST WYOMING AND NORTHWEST COLORADO
}

\author{
By Henry W. Roehler
}

\begin{abstract}
The report names and describes the Godiva Rim Member of the Green River Formation in the eastern part of the Washakie basin in southwest Wyoming and the central part of the Sand Wash basin in northwest Colorado. The Godiva Rim Member comprises lithofacies of mixed mudflat and lacustrine origin situated between the overlying lacustrine Laney Member of the Green River Formation and the underlying fluvial Cathedral Bluffs Tongue of the Wasatch Formation. The Godiva Rim Member is laterally equivalent to and grades westward into the LaClede Bed of the Laney Member.

The type section of the Godiva Rim Member is located on Bald Mountain at the northeast end of Godiva Rim in the Sand Wash basin. The type section is 324 feet thick and consists mostly of gray and green mudstone that is interbedded with brown oil shale, gray-brown silty kerogenaceous shale, gray or tan sandstone and siltstone, and gray shale. Very thin beds of gray limestone and brown algal limestone also are present locally. Fossil mammal determinations indicate that the age of the member is early middle Eocene.

The Godiva Rim Member of the Green River Formation was deposited along the southeast margins of Lake Gosiute and is correlated to similar lithologic units that were deposited along the northeast margins of Lake Uinta in the Parachute Creek Member of the Green River Formation. The stratigraphic data presented provide significant evidence that the two lakes were periodically connected around the east end of the Uinta Mountains during the middle Eocene.
\end{abstract}

\section{INTRODUCTION}

The name Godiva Rim Member of the Green River Formation is herein applied to an interval of $160-375 \mathrm{ft}$ of mudstone, shale, oil shale, sandstone, siltstone, and limestone all of which crop out between the overlying Laney Member of the Green River Formation and the underlying Cathedral Bluffs Tongue of the Wasatch

\footnotetext{
Manuscript approved for publication April 12, 1990.
}

Formation across the central part of the Sand Wash basin in northwest Colorado and the eastern part of the Washakie basin in southwest Wyoming. The member comprises rocks that were deposited in and adjacent to Eocene Lake Gosiute. Lake Gosiute occupied the intermontane greater Green River basin (fig. 1), which includes the Sand Wash and Washakie basins.

The Godiva Rim Member is named for exposures along the southeast slopes of Godiva Rim in the Sand Wash basin in T. 8 N., R. 96 W., Moffat County, Colo. (fig. 2). The member is easily identified in outcrops by its distinct gray-weathering color, which sharply contrasts with the tan-weathering Laney Member of the Green River Formation and the mostly red- and gray-weathering Cathedral Bluffs Tongue of the Wasatch Formation. The Godiva Rim Member has been mapped previously, but has not been formally named. Recognition of the member as a formal stratigraphic unit completes a stratigraphic framework prepared by the author for the Wasatch, Green River, and Bridger (Washakie) Formations in the greater Green River basin (fig. 3).

\section{PREVIOUS INVESTIGATIONS}

The first detailed investigation of the geology of Eocene rocks in the Sand Wash and Washakie basins was undertaken in 1921 and 1922 by J.D. Sears and W.H. Bradley. Sears and Bradley (1925, pl. 24) published a geologic map of the Sand Wash and Washakie basins on which the stratigraphic interval of the Godiva Rim Member was included in the Cathedral Bluffs Tongue of the Wasatch Formation. On later more detailed geologic 


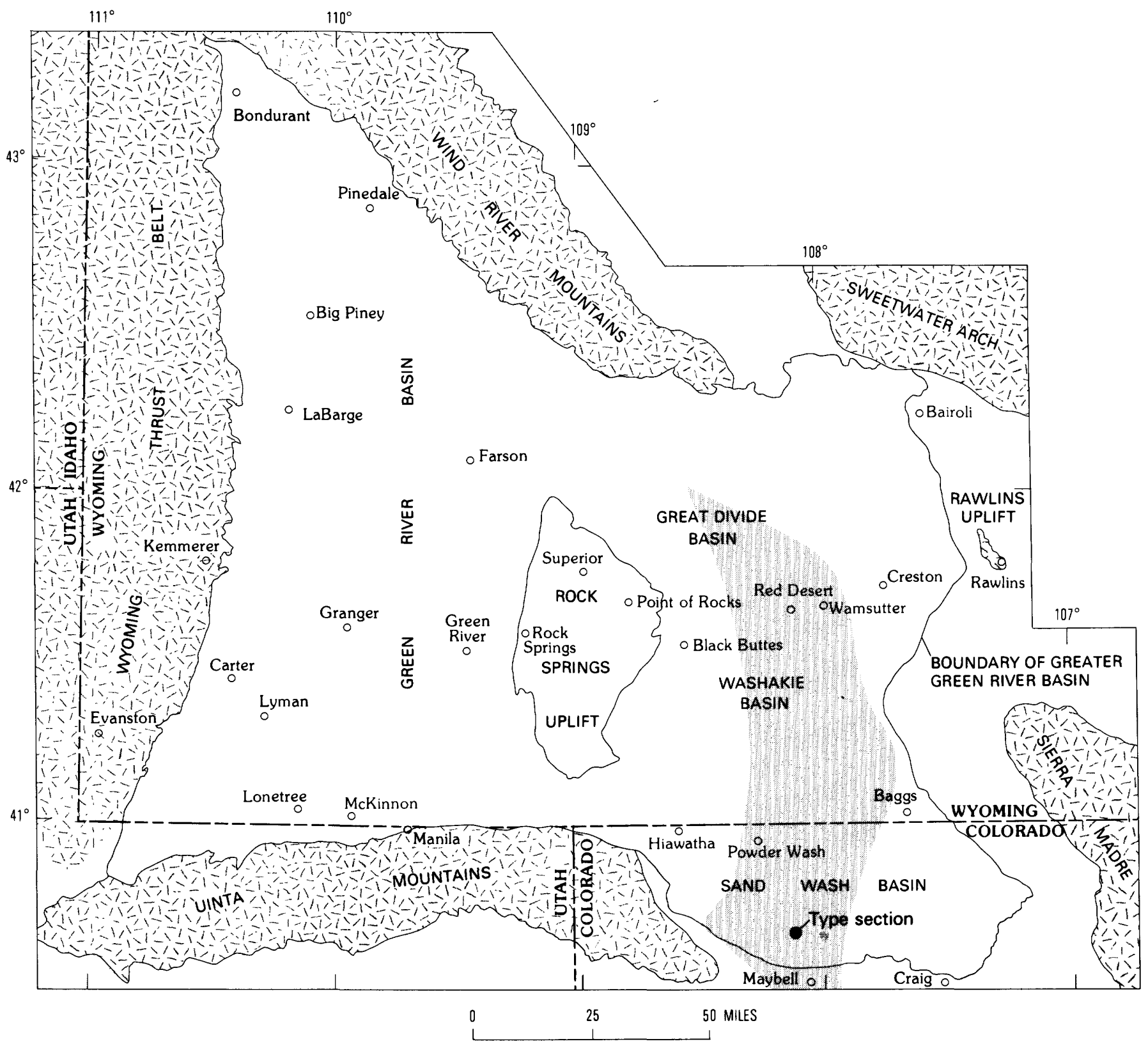

FIGURE 1.-Location of greater Green River basin and the approximate Eocene areal distribution (shaded) of the Godiva Rim Member of the Green River Formation.

maps of the Washakie basin, Bradley $(1945 ; 1964$, pl. 1) included the same interval in the basal part of the Laney Member of the Green River Formation. Roehler (1985) assigned these rocks to the basal unnamed tongue of the Laney.

The basal part of the Laney Member of the Green River Formation and the upper part of the underlying Cathedral Bluffs Tongue of the Wasatch Formation are shown to be intertongued in the eastern Washakie basin on a geologic map published by Roehler (1973a, fig. 1, p. 48). This intertonguing is also shown by Love and Christiansen (1985) on the geologic map of Wyoming. As a result of my recent field work in the area, the intertongued interval is herein designated the Godiva Rim Member.

The Godiva Rim Member was identified and mapped as the "gray zone" at the top of the Wasatch Formation by McKay and Bergin (1974) on the Maybell quadrangle in the Sand Wash basin. A segment of this quadrangle that includes the Godiva Rim area is shown in figure 4 . The 


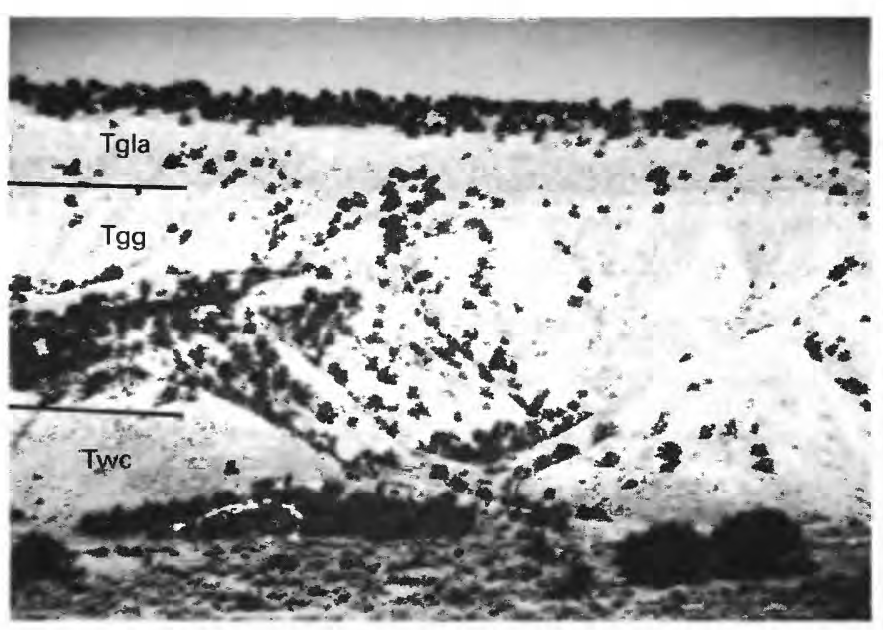

Figure 2.-Outcrops of the Laney Member (Tgla) and Godiva Rim Member (Tgg) of the Green River Formation and the Cathedral Bluffs Tongue (Twc) of the Wasatch Formation on the southeast slopes of Godiva Rim. View is to the west in sec. 10 , T. 8 N., R. 96 W. The Godiva Rim Member is about $250 \mathrm{ft}$ thick at this location.

gray zone (Tgg, fig. 4) was described by them as about $200 \mathrm{ft}$ of gray interbedded claystone and siltstone, and gray and buff flat-bedded and crossbedded fine-grained sandstone.

My stratigraphic investigations of the Godiva Rim Member began in July 1987, when I measured a section of the Cathedral Bluffs Tongue of the Wasatch Formation and the Laney Member of the Green River Formation on the southeast slopes of Godiva Rim in secs. 20, 27,28 , and 29 , T. 8 N., R. 96 W. (fig. 4). In this section the unit mapped as the gray zone of the Wasatch Formation by McKay and Bergin (1974) was discovered to be primarily composed of interbedded lacustrine, shoreline, and mudflat deposits that are normally included in the Green River Formation. Later in 1987, I measured several additional sections along outcrops of the gray zone across the central part of the Sand Wash basin and eastern part of the Washakie basin. The gray zone was consistently present in these sections, but it gradually thinned northward across the basins where it was replaced from the base upward by the Cathedral Bluffs Tongue of the Wasatch Formation. The interbedded lacustrine, shoreline, and mudflat deposits of the gray zone were then correlated in the subsurface by drill holes and coreholes to sections measured along the eastern and western margins of the Sand Wash and Washakie basins. These investigations resulted in my designating a new formal stratigraphic unit in the Green River Formation, the Godiva Rim Member, which supersedes the term gray zone of the Wasatch Formation used by McKay and Bergin (1974).

\section{LOCATION AND DESCRIPTION OF TYPE SECTION}

The type section of the Godiva Rim Member lies on the east slopes of Bald Mountain (fig. 5) at the northeast end of Godiva Rim in NE1/4 sec. 1, T. 8 N., R. 96 W. (fig. 4). The type section is accessible by Moffat County road 19, which branches northward from U.S. Highway 40 at Maybell, Colo. Twelve miles north of Maybell in SE sec. 32 , T. 9 N., R. 95 W., a secondary gravel road joins county road 19 from the southwest. Bald Mountain is located on the west side of this road, 2 miles southwest of the road junction. Rocks composing the type section and adjacent rocks in the Laney Member and Cathedral Bluffs Tongue are illustrated in a columnar section, figure 6. Lithologies, interpreted depositional environments, and thicknesses of rock units are listed in the following descriptions.

Type section of the Godiva Rim Member of the Green River Formation, with parts of the overlying Laney Member of the Green River

Formation and underlying Cathedral Bluffs Tongue of the Wasatch Formation

[Measured by Jacob's staff on the east slopes of Bald Mountain in NE1/4 sec. 1, T. 8 N., R. $96 \mathrm{~W} .1$

Thickness Feet

LaClede Bed of Laney Member of Green River

Formation (part):

72. Ostracodal sandstone, gray, very fine grained, limy, hard; in thin parallel beds; nearshore lacustrine deposit; caps ledge at the top of Bald Mountain ...

71. Oil shale, brown, flaky, soft; offshore lacustrine deposit

70. Sandstone, gray, fine-grained, fairly well sorted, very limy; in thin parallel beds; abundant ostracodes, oolites and fish bones; lacustrine shoreline deposit ....

69. Oil shale, brown, flaky, soft; offshore lacustrine deposit

129.0

68. Tuff, rust, deeply weathered, soft; airfall volcanic ash deposit.

67. Oil shale, brown, flaky, soft; offshore lacustrine deposit

0.8

66. Tuff, rust, deeply weathered, soft; airfall volcanic ash deposit.

65. Oil shale, brown, flaky, soft; offshore lacustrine deposit

Total LaClede Bed measured

Godiva Rim Member (type) of Green River

Formation:

64. Sandstone, tan, very fine grained, argillaceous, micaceous, soft, loose; vague parallel bedding; lacustrine shoreline deposit....

63. Mudstone, gray-green, flaky to shaly, soft; mudflat deposit 
Type section of the Godiva Rim Member, with parts of the Laney Member and Cathedral Bluffs Tongue-Continued

Godiva Rim Member (type) of Green River FormationContinued

62. Siltstone, tan, argillaceous, very soft; lacustrine shoreline deposit

61. Shale, gray-brown, flaky, soft; becomes gray toward the top; low kerogen content; offshore lacustrine deposit.....

60. Sandstone, gray, very fine grained, calcareous; abundant muscovite and biotite grains; in thin parallel, partly current rippled laminae; lacustrine shoreline deposit

59. Mudstone, gray, gray-green, partly silty; and interbedded shale, gray, gray-brown, fissile, traces of kerogen; mudflat and nearshore lacustrine deposits.

58. Oil shale, brown, flaky, soft; offshore lacustrine deposit

57. Mudstone, gray-green, soft, a few sandy layers; becomes shaly upwards; mudflat deposit .........

56. Sandstone, gray, fine to very coarse grained, poorly sorted, subangular, micaceous, mostly soft and loose; fines upward; vague trough crossbedding; a local, lenticular fluvial channel deposit

55. Mudstone, gray-green, silty, soft; mudflat deposit

54. Sandstone, tan, very fine grained, soft, loose; splay deposit

53. Mudstone, dark-gray-green, silty, soft; mudflat deposit

52. Sandstone, gray, very fine grained, calcareous, fairly well sorted; in current rippled laminae; splay deposit

51. Mudstone, gray-green, flaky, soft; mudflat deposit

50. Oil shale, brown, flaky, soft; abundant ostracodes; offshore lacustrine deposit

49. Mudstone, gray, gray-green, silty, soft; mudflat deposit .

48. Shale, gray, gray-brown, fissile, soft; trace of kerogen; nearshore lacustrine deposit

47. Mudstone, dark-gray-green, blocky, soft; some very silty layers, some shaly layers; mudflat deposits .....

46. Oil shale, tan, very silty, soft, deeply weathered; scattered ostracodes; offshore lacustrine deposit

45. Limestone, tan, silty, hard, dense; scattered small gray clay pebbles; abundant ostracodes; a few algal colonies; weathers to brown ledge; lacustrine shoreline deposit.

44. Mudstone, gray-green, blocky, some shaly, silty, soft; mudflat deposit

43. Limestone, tan, hard, dense, massive; weathers to brown jointed ledge; offshore lacustrine deposit

42. Oil shale, brown, flaky to papery, soft, partly silty; scattered small plant fragments; offshore lacustrine deposit.

41. Shale, gray-brown, very silty in the lower part, firm; trace of kerogen; offshore lacustrine deposit
Thickness

Feet

1.1

34.9

7.8

21.2

20.2

10.4

2.7

0.4

8.6

16.1

28.5

2.0

25.4

0.7

Type section of the Godiva Rim Member, with parts of the Laney Member and Cathedral Bluffs Tongue-Continued

Godiva Rim Member (type) of Green River Formation-

Continued

40. Mudstone, dark-gray-green, soft; mudflat deposit

39. Oil shale, brown, flaky, soft; scattered ostracodes; offshore lacustrine deposit ....

38. Shale, gray-brown, fissile, soft; trace of kerogen; offshore lacustrine deposit

37. Mudstone, gray-green, very silty to sandy, soft; mudflat deposit

36. Sandstone, gray, very fine to fine grained, fairly well sorted, slightly calcareous; scattered red and black grains; in thin current-rippled laminae; and a few interlaminated shale beds, gray, the lower $3.0 \mathrm{ft}$; splay deposit

35. Mudstone, dark-gray-green, blocky, soft, noncalcareous; mudflat deposit

34. Sandstone, gray, very coarse grained in a very fine grained matrix, poorly sorted, subangular, slightly calcareous; abundant gray and milky quartz grains; scattered black and red grains; in small-scale trough crossbeds; fluvial channel deposit

33. Mudstone, gray, gray-green, blocky, silty; becomes shaly the top $3.0 \mathrm{ft}$; mudflat deposit...

32. Ostracodal sandstone, gray, brown-weathering, very fine grained; in thin undulating beds; some worm trails on the upper surface; lacustrine shoreline deposit

31. Mudstone, dark-gray-green, fissile to blocky, soft; mudflat deposit

30. Sandstone, tan-rust, very fine grained, soft, loose; lacustrine shoreline deposit.

29. Ostracodal siltstone, gray, calcareous; in thin subparallel wave-rippled laminae; weathers to small bench; lacustrine shoreline deposit

Thickness

Feet

4.8

28. Mudstone, dark-green, blocky, soft, noncalcareous; mudflat deposit.

27. Oil shale, brown, flaky, soft; abundant ostracodes; offshore lacustrine deposit .

26. Shale, gray-brown, silty, firm, trace of kerogen; offshore lacustrine deposit .

Total thickness of the Godiva Rim Member...

Cathedral Bluffs Tongue of Wasatch Formation (part):

25. Mudstone, gray-green, soft; flood-basin deposit...

24. Sandstone, gray, very fine grained, slightly calcareous; in parallel laminae; flood-plain splay deposit ....

23. Mudstone, gray-green, some mottled maroon the lower $4.0 \mathrm{ft}$; and two $0.3-\mathrm{ft}$-thick beds of siltstone, gray, calcareous, in parallel laminae, 6.0 and $15.0 \mathrm{ft}$ above the base; flood-basin and flood-plain splay deposits

22. Mudstone, maroon, soft; flood-basin deposit

21. Mudstone, gray-green, silty, soft; flood-basin deposit.....

20. Mudstone, maroon, soft; flood-basin deposit........

ess


Type section of the Godiva Rim Member, with parts of the Laney Member and Cathedral Bluffs Tongue-Continued

\section{Cathedral Bluffs Tongue of Wasatch Formation} (part)-Continued

19. Siltstone, gray, calcareous, crumbly; weathers to small blocks; flood-plain splay deposit .............

18. Mudstone, gray-green, soft; flood-basin deposit...

17. Mudstone, maroon, soft; flood-basin deposit........

16. Mudstone, gray-green, silty, soft; flood-basin deposit

15. Siltstone, gray, slightly calcareous; in parallel laminae; flood-basin splay deposit

14. Mudstone, gray-green, silty, soft; flood-basin deposit .................................................

13. Mudstone, maroon, blocky, soft; flood-basin deposit

12. Mudstone, gray-green, silty, soft; flood-basin deposit .....

11. Sandstone, gray, very fine grained, silty, slightly calcareous; in thin parallel laminae; flood-plain splay deposit

10. Mudstone, gray-green, soft; flood-basin deposit...

9. Mudstone, maroon, soft; flood-basin deposit........

8. Mudstone, gray-green, soft, silty in the lower part; flood-basin deposit.

7. Sandstone, gray, very fine to fine grained, slightly calcareous; abundant dark grains, large grains of muscovite; in very low angle trough crosslaminations; flood-plain splay deposit .............

6. Mudstone, gray, silty, soft; flood-basin deposit...

5. Mudstone, maroon, silty, soft; flood-basin deposit

4. Mudstone, green, silty, soft; flood-basin deposit ..

3. Mudstone, maroon, silty, soft; flood-basin deposit

2. Sandstone, gray, fine- to coarse-grained, poorly sorted, subangular, soft, loose; abundant muscovite grains; vague trough crossbedding; fluvial channel deposit

1. Mudstone, maroon, brick-red, gray, banded, in bands as much as $15 \mathrm{ft}$ thick, silty, soft; floodbasin deposit

Total Cathedral Bluffs Tongue measured...... flowed across the mudflats toward contracted parts of the lake as evidenced by widely spaced channel sandstones. From these stream channels splays fanned outward onto the adjacent mudflats.

The lithologies of the type section of the Godiva Rim Member reveal that Lake Gosiute expanded and contracted across the Bald Mountain area at least 10 times. Periods of maximum expansion are indicated by beds of gray-brown kerogenaceous shale (type section, beds $26,38,41,48,59$, and 61 ) and brown oil shale (beds $27,39,42,46,50$, and 58). The thickest oil shale bed (bed 50 ) is $16 \mathrm{ft}$ thick, and its deposition probably took several thousand years. Shorelines in the type section consist of tan or gray, partly ostracode bearing, parallel-bedded siltstone and sandstone (beds $29,30,32,60,62$, and 64) and tan ostracodal limestone and sandstone (bed 45). Most of the rocks in the section consist of gray or green mudflat mudstone (beds $28,31,33,35,37,40,44,47,49$, $51,53,55,57,59$, and 63 ). Two gray, fine to very coarse grained, lenticular, trough-crossbedded, fluvial channel sandstones (beds 34 and 56) are present in the lower and upper parts of the section. A few thin gray or tan, current-rippled, splay sandstones (beds 36,52 , and 54) are interbedded with the mudflat mudstone. One thin tan limestone of probable offshore lacustrine origin (bed 43) was also identified.

The lithologic composition and genesis of the Godiva Rim Member are very similar to those of the Wilkins Peak Member of the Green River Formation (fig. 3). The units are not chronostratigraphic equivalents, however, and they occupy different geographic parts of the greater Green River basin.

The climate during deposition of the Godiva Rim Member was subtropical with an average annual temperature of about $70{ }^{\circ} \mathrm{F}$ and average precipitation of nearly 60 inches. These estimates were interpreted from plant megafossils collected by H.D. MacGinitie (written commun., 1970). The expansions and contractions of Lake Gosiute across the Sand Wash and Washakie basins undoubtedly are climate related and suggest that within the average temperature and precipitation ranges determined by MacGinitie are numerous cyclic climate changes of lesser duration. The periodicity and extent of the lesser climate changes have not been determined, but I speculate that they occurred every 15 to 25 thousand years and that they were worldwide.

\section{AREAL DISTRIBUTION AND CORRELATION}

The Godiva Rim Member was deposited across an area of about $2,600 \mathrm{mi}^{2}$ that comprises the central part of the Sand Wash basin, the eastern part of the Washakie siltstone, and limestone occur intermittently in association with the oil shale and mudstone. At times streams deposited along the eastern margins of the basin of Lake Gosiute during east-west expansions and contractions of the lake waters across the Sand Wash and Washakie basins. Oil shale was deposited in offshore and nearshore areas during expanded phases of the lake, and as the lake waters retreated, the exposed featureless parts of the former lake bottom became broad mudflats on which muds were deposited. Ephemeral shoreline sandstone 


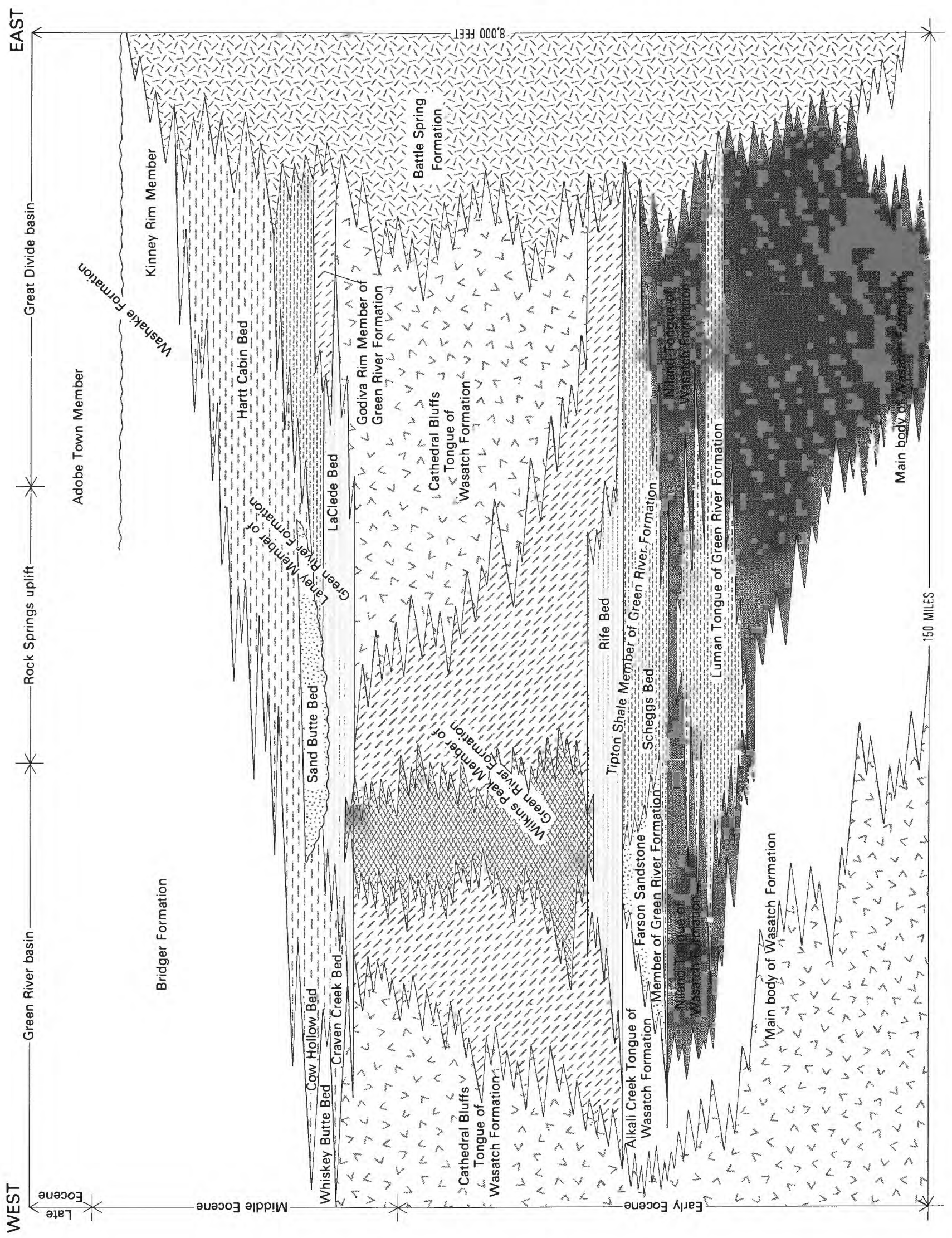




\section{EXPLANATION}

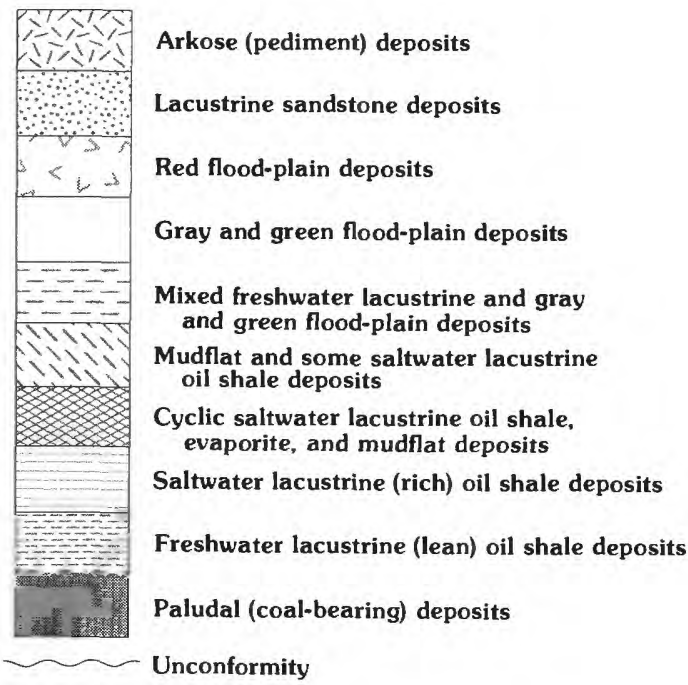

FIGURE 3 (above and facing page). - Generalized cross section of Eocene rocks in greater Green River basin showing stratigraphic nomenclature and depositional environments.

basin, and the south-central part of the Great Divide basin. The precise areal distribution of the Godiva Rim Member cannot be determined, because it has been eroded from the Great Divide basin and from the areas east of where it crops out in the Sand Wash and Washakie basins. Moreover, the member intertongues with and grades laterally westward into the LaClede Bed of the Laney Member, making its western boundary arbitrary. Its approximate Eocene areal distribution is shown in figure 1 .

The stratigraphic relationships of the Godiva Rim Member with the overlying Laney Member of the Green River Formation and the underlying Cathedral Bluffs Tongue of the Wasatch Formation in the Sand Wash and Washakie Basins are illustrated in figure 7. In the three transbasin cross sections shown in figure 7, the Godiva Rim Member is replaced laterally westward by the lower part of the LaClede Bed of the Laney Member. Along Kinney Rim in the western part of the Washakie basin (nos. 1 and 4, fig. 7), and along Lookout Mountain in the western part of the Sand Wash basin (no. 8, fig. 7), the lower part of the LaClede Bed is composed of oil shale and interbedded tuff and tuffaceous sandstone and siltstone. The thickest of the tuffaceous sandstone and siltstone beds in this part of the section is called the buff marker bed (Roehler, 1973b, p. E6-E7), which is easily correlated in outcrops and on electric logs. Along Kinney Rim the buff marker is locally more than $50 \mathrm{ft}$ thick and forms a distinct massive buff band in outcrops between overlying and underlying parallel-bedded oil shale beds that weather brown and gray (fig. 8). Eastward across the Sand Wash and Washakie basins, the oil shale in the lower part of the LaClede Bed grades laterally into the mudstone, shale, sandstone, and limestone that compose the Godiva Rim Member (fig. 7). Where the Godiva Rim Member crops out across the central part of the Sand Wash basin (fig. 9) and across the eastern part of the Washakie basin, it bears little resemblance to its lateral equivalents in the lower part of the LaClede Bed (compare figs. 8 and 9 ).

\section{AGE OF THE GODIVA RIM MEMBER}

The age of the Godiva Rim Member is early middle Eocene based on the stratigraphic occurrence of agediagnostic fossil mammals collected in the eastern part of the Washakie basin. No fossil mammals have been collected from the Godiva Rim Member itself, but they have been collected from overlying and underlying rocks that bracket the member. McGrew and Roehler (1960, p. 158) collected Sciuravus nitidus from a 15 -ft-thick sandstone bed located $75 \mathrm{ft}$ below the top of the Cathedral Bluffs Tongue of the Wasatch Formation in NW $1 / 4$ sec. 8, T. 15 N., R. 93 W. (near section 7, fig. 7, this report). In 1969 I collected (unpublished data) the mammals Nyctitherium serotinum and Omomys sp. from a 0.4 -ft-thick bed of mollusk-bearing black chert situated $9.5 \mathrm{ft}$ below the base of the green shale marker bed in the upper part of the LaClede Bed of the Laney Member of the Green River Formation in $\mathrm{NE}^{1 / 4}$ sec. 36, T. 18 N., R. 95 W. (section 3, fig. 7).

\section{PALEOGEOGRAPHY}

The Godiva Rim Member, as discussed previously, thickens from north to south along the eastern part of the Washakie basin and the central part of the Sand Wash basin (figs. 1 and 7). The thickening occurs in directions away from the deep parts of Lake Gosiute where kerogenaceous shale and oil shale were deposited (no. 1, fig. 10) but toward the basin margin south of Godiva Rim where the member is eroded around the east end of the Uinta Mountains. These relationships suggest that during the middle Eocene, equivalents of the Godiva Rim Member were deposited continuously around the east end of the Uinta Mountains through a broad depression or channel that connected Lake Gosiute to the north with Lake Uinta to the south (index map, fig. 10). The presence of a channel there is further suggested by the occurrence of mudflat mudstones at the stratigraphic interval of the Godiva Rim Member in the Piceance Creek basin 33 miles south of Godiva Rim on the south 


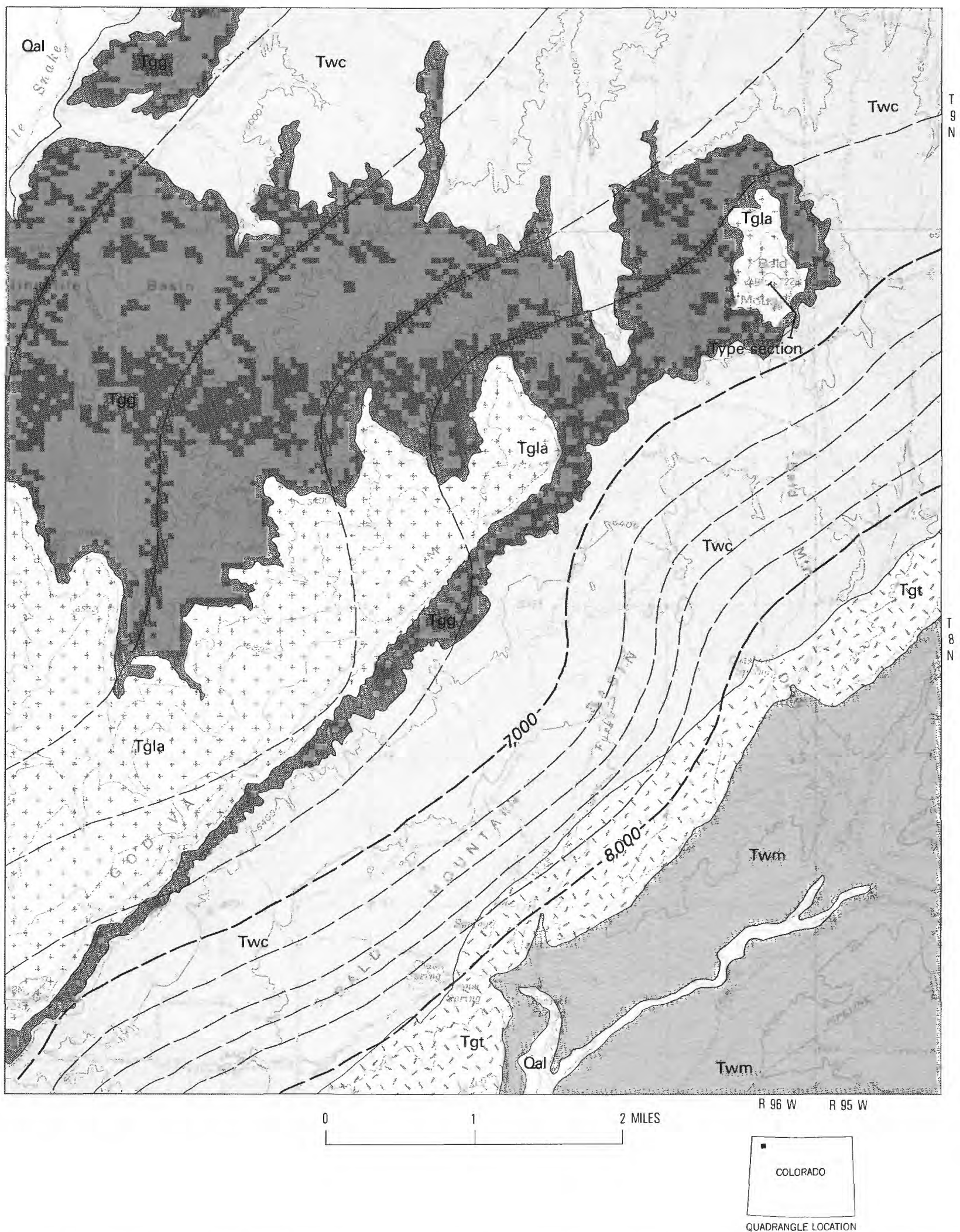

FIGURE 4.-Geologic map of the Godiva Rim area showing location of the type section of the Godiva Rim Member of the Green River Formation on Bald Mountain in sec. 1, T. 8 N., R. 96 W. (Modified from McKay and Bergin, 1974.) Qal, Quaternary alluvium; Tgla, Laney Member of Green River Formation; Tgg, Godiva Rim Member of Green River Formation (the gray zone); Twc, Cathedral Bluffs Tongue of Wasatch Formation; Tgt, Scheggs Bed of the Tipton Tongue of Green River Formation; Twm, main body of Wasatch Formation. Structure contour interval $200 \mathrm{ft}$; dashed where approximately located; datum is the base of the Laney Member. Base from Maybell 1:62,500 (1958). . 


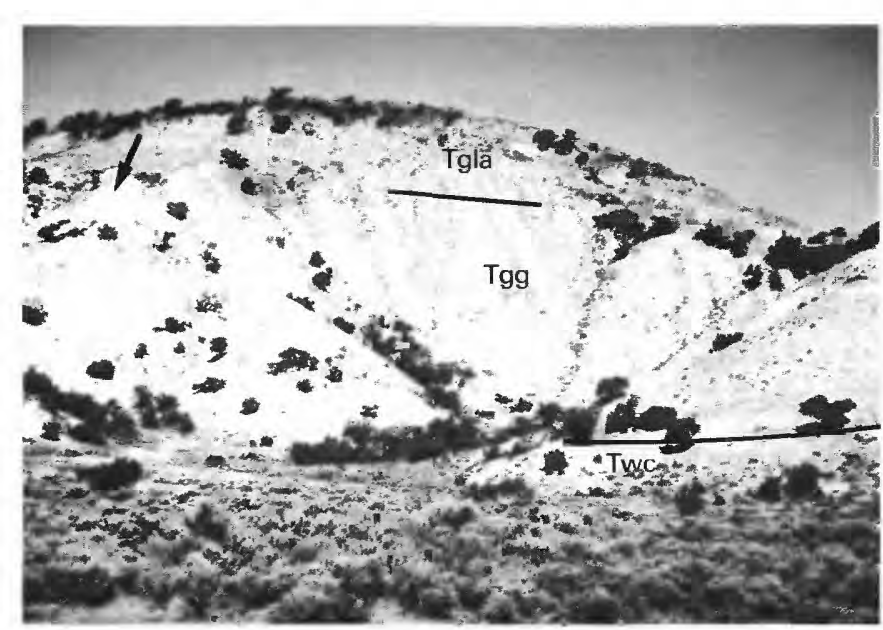

Figure 5.-Type section of the Godiva Rim Member of the Green River Formation, east slopes of Bald Mountain, NE1/4 sec. 1, T. 8 N., R. $96 \mathrm{~W}$. (fig. 4). Arrow indicates sloping ridge where the type section was measured. Tgla, Laney Member of Green River Formation; Tgg, Godiva Rim Member of Green River Formation; Twc, Cathedral Bluffs Tongue of Wasatch Formation. The Godiva Rim Member is $324 \mathrm{ft}$ thick at this location.

side of the Uinta Mountains (Roehler, 1974). These mudflat deposits, informally called the green facies, are situated in the Parachute Creek Member of the Green River Formation at the mouth of Yellow Creek (no. 3, fig. 10). A few miles southeast of the mouth of Yellow Creek, at the U.S. Bureau of Mines Yellow Creek Corehole No. 1 (no. 4, fig. 10), these mudflat mudstones have graded laterally into oil shale that was deposited in deep parts of Lake Uinta. Correlation of the buff marker in the LaClede Bed to part of the interval between A Groove and B Groove in the Parachute Creek Member, shown in figure 10, was first proposed by Roehler (1974, p. 64 , fig. 4).

The lithologic units shown in the columns on figure 10 suggest that Lake Gosiute and Lake Uinta were joined as a single body of open water at least three times during the middle Eocene. The earliest juncture of the lakes probably occurred at interval A, which consists of oil shale and slightly kerogenaceous shale beds located at the base of the Godiva Rim Member on Godiva Rim (no. 2, fig. 10) that correlate to similar oil shale beds situated about $320 \mathrm{ft}$ below the Mahogany Bed at the mouth of Yellow Creek (no. 3, fig. 10). The second juncture of the lakes probably occurred at interval B, which consists of oil shale beds underlying the buff marker (nos. 1 and 2, fig. 10), that correlate to the Mahogany Bed (nos. 3 and 4, fig. 10). The third and most prolonged juncture of the lakes took place during deposition of the beds in interval $\mathrm{C}$ (nos. 1, 2, 3, and 4, fig. 10).

\section{REFERENGES CITED}

Bradley, W.H., 1945, Geology of the Washakie basin, Sweetwater and Carbon Counties, Wyoming and Moffat County, Colorado: U.S. Geological Survey Oil and Gas Investigations Preliminary Map 32, scale $1: 190,000,1$ sheet.

1964, Geology of Green River Formation and associated Eocene rocks in southwestern Wyoming and adjacent parts of Colorado and Utah: U.S. Geological Survey Professional Paper 496-A, 86 p.

Love, J.D., and Christiansen, A.C., 1985, Geologic map of Wyoming: U.S. Geological Survey, 2 sheets.

McGrew, P.O., and Roehler, H.W., 1960, Correlation of Tertiary units in Southwestern Wyoming, in McGookey, D.P., and Miller, D.N., Jr., eds., Overthrust belt of southwestern Wyoming and adjacent areas: Wyoming Geological Association Guidebook, 15th Annual Field Conference, Wyoming, p. 156-158.

McKay, E.J., and Bergin, M.J., 1974, Geologic map of the Maybell quadrangle, Moffat County, Colorado: U.S. Geological Survey Geologic Quadrangle Map GQ-1145, scale 1:62,500.

Roehler, H.W., 1973a, Mineral resources in the Washakie basin, Wyoming and Sand Wash basin, Colorado, in Schell, E.M., ed., Wyoming Geological Association Guidebook, 25th Field Conference, Greater Green River basin Symposium: Casper, Wyoming, p. 47-56.

$1973 \mathrm{~b}$, Stratigraphic divisions and geologic history of the Laney Member of the Green River Formation in the Washakie basin in southwestern Wyoming: U.S. Geological Survey Bulletin 1372-E, 28 p.

1974, Depositional environments of rocks in the Piceance Creek basin, Colorado, in Murray, D.K., Energy resources of the Piceance Creek Basin: Rocky Mountain Association of Geologists Guidebook, 25th Field Conference, Denver, Colo., p. 57-64.

1985, Geologic map of the Kinney Rim $30 \times 60$ minute quadrangle, Wyoming and Colorado: U.S. Geological Survey Miscellaneous Investigations Series Map I-1615, scale 1:100,000.

Sears, J.D., and Bradley, W.H., 1925, Relations of the Wasatch and Green River Formations in northwestern Colorado and southern Wyoming, with notes on oil shale in the Green River Formation: U.S. Geological Survey Professional Paper 132, p. 93-107. 


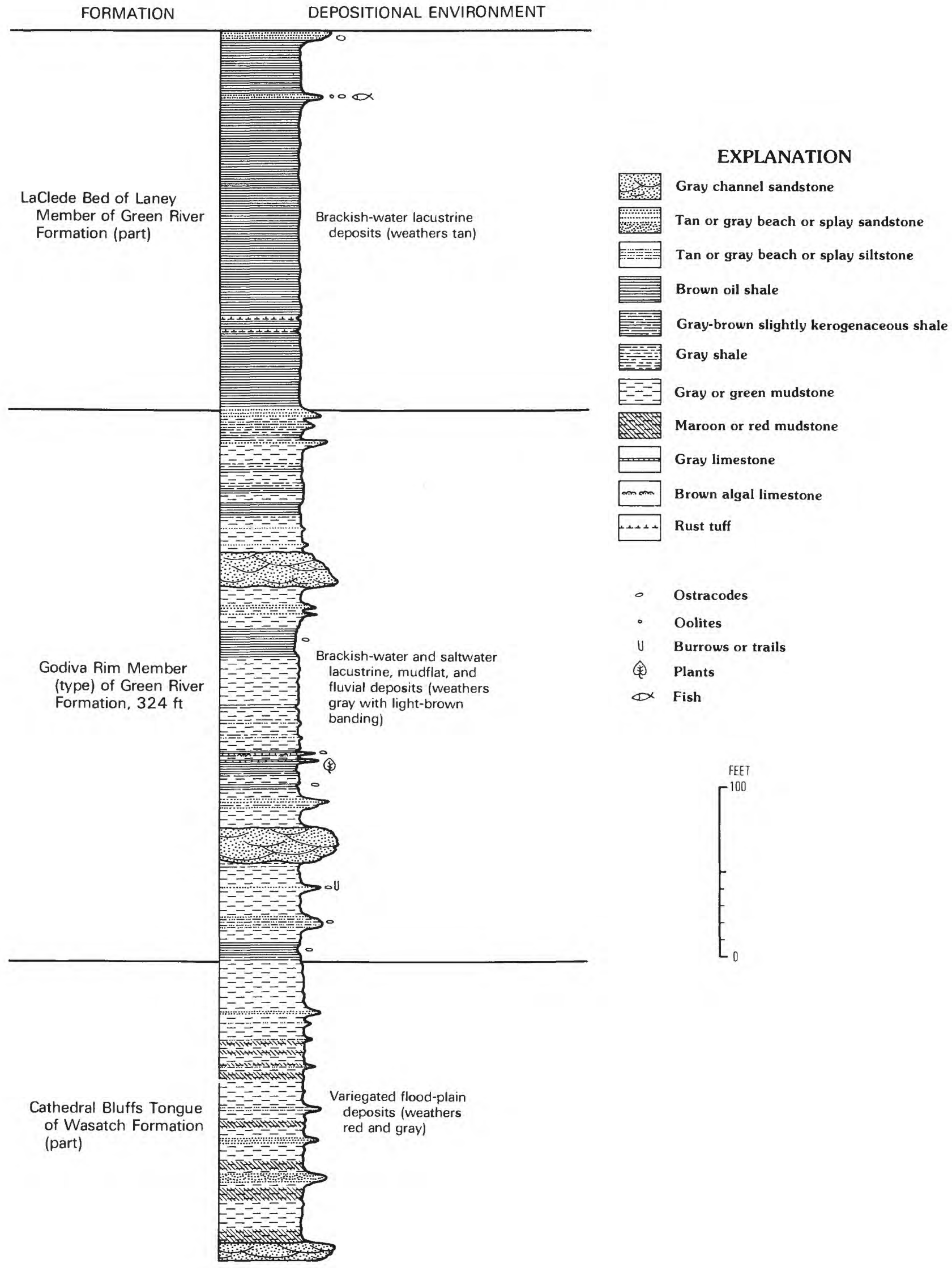

Figure 6.-Columnar section of the Godiva Rim Member and adjacent rocks in the Green River and Wasatch Formations. Location of the section is shown in figure 4 . 


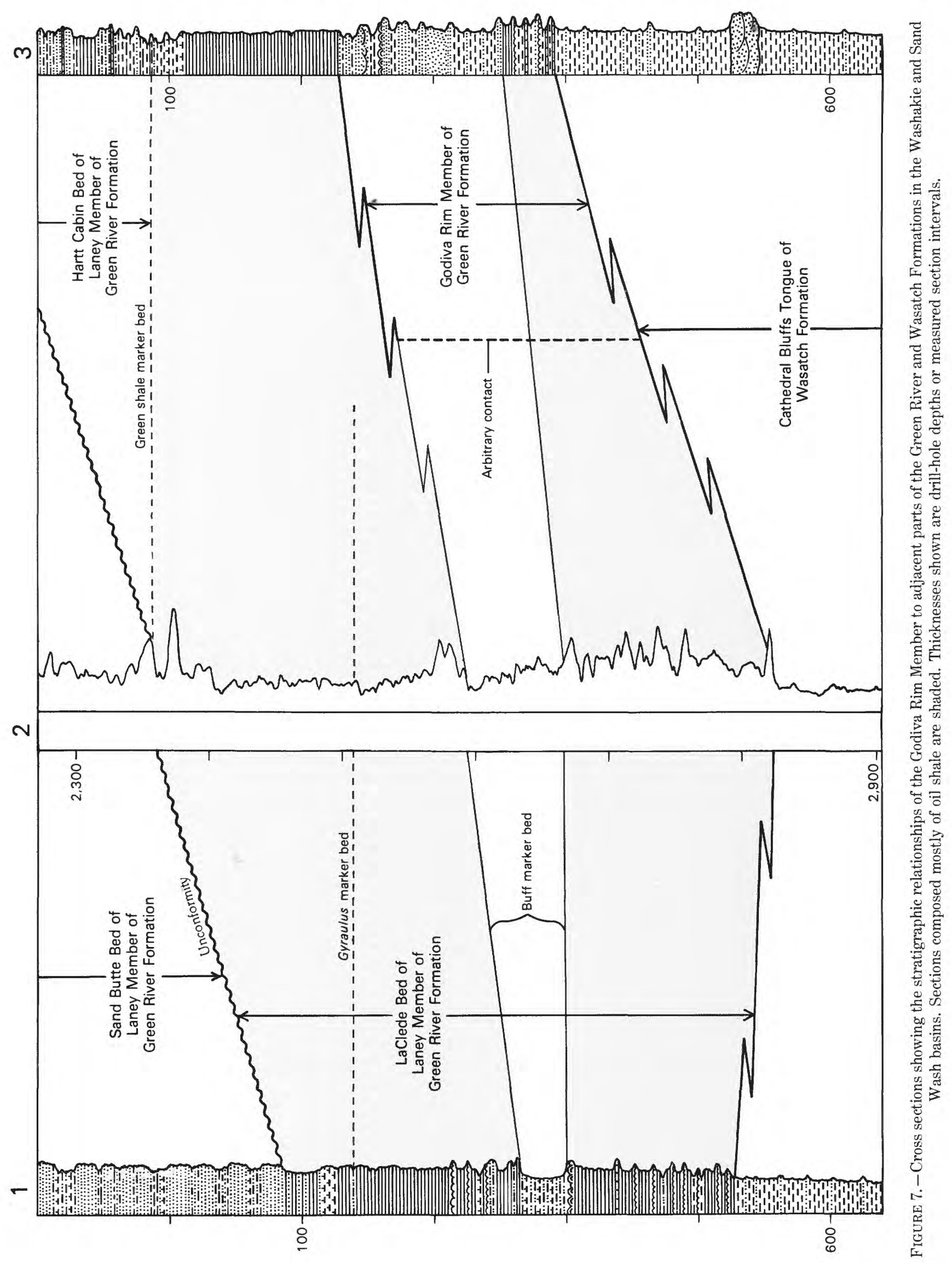




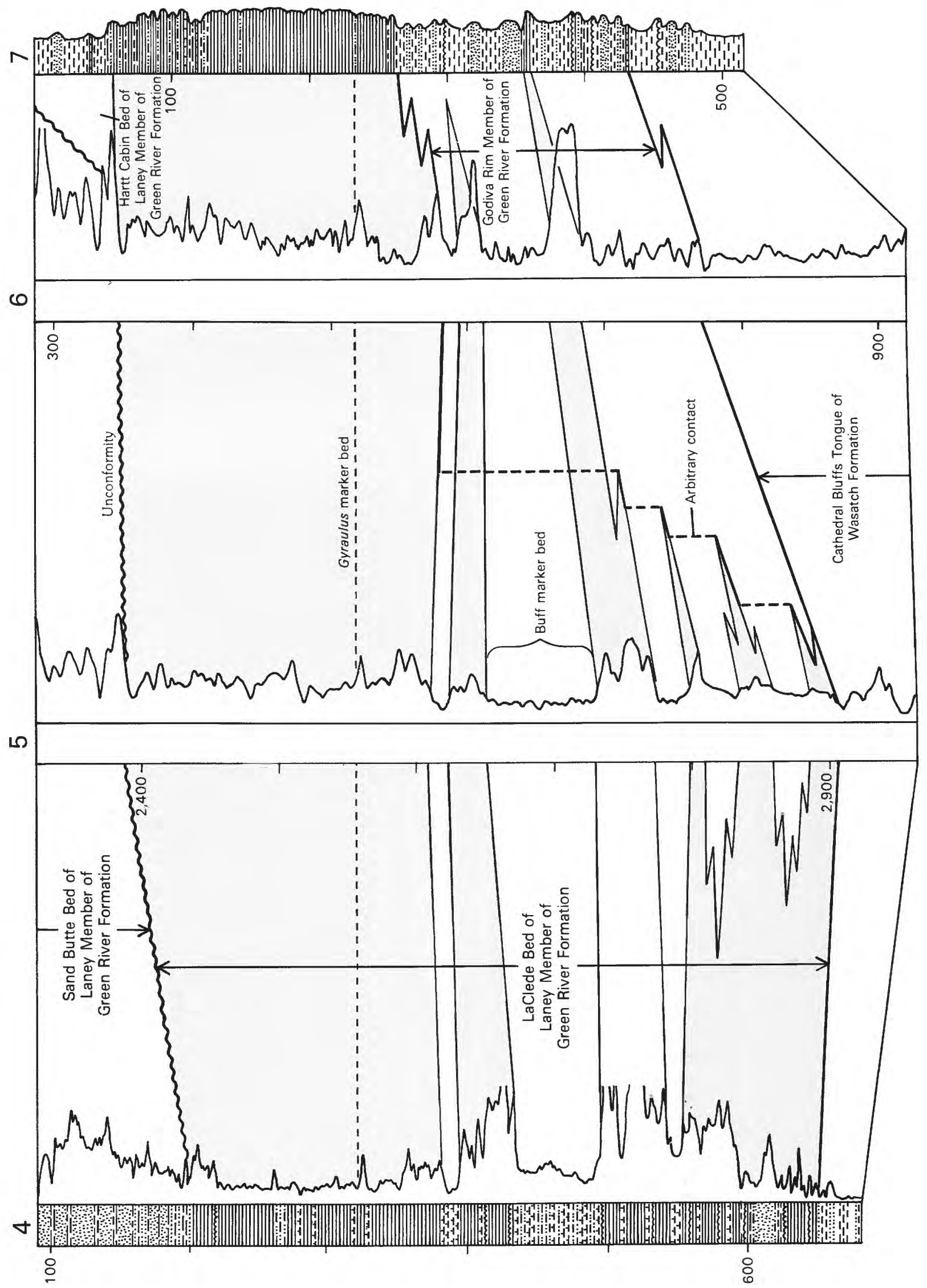


GODIVA RIM MEMBER, GREEN RIVER FORMATION, WYOMING AND COLORADO

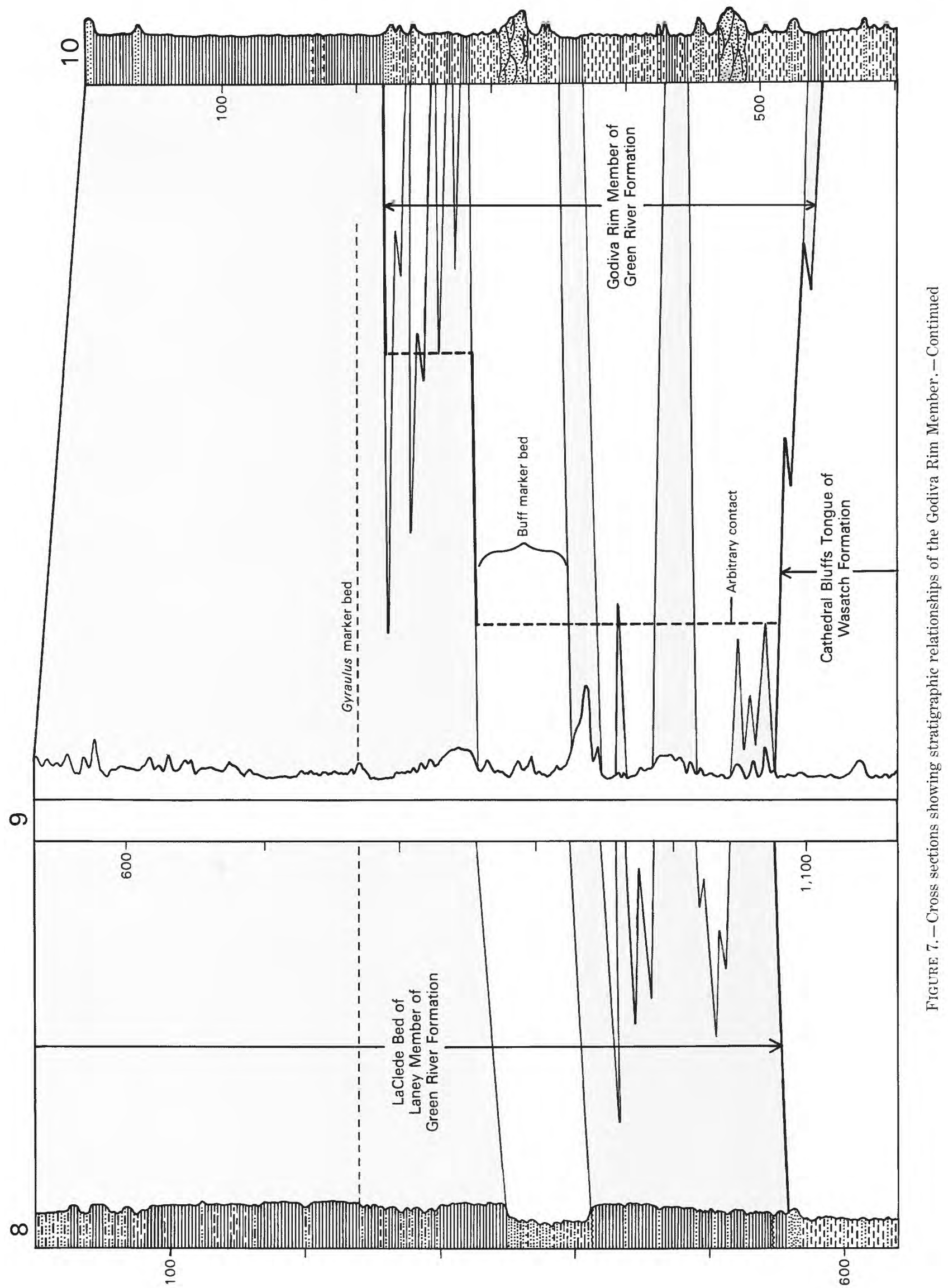



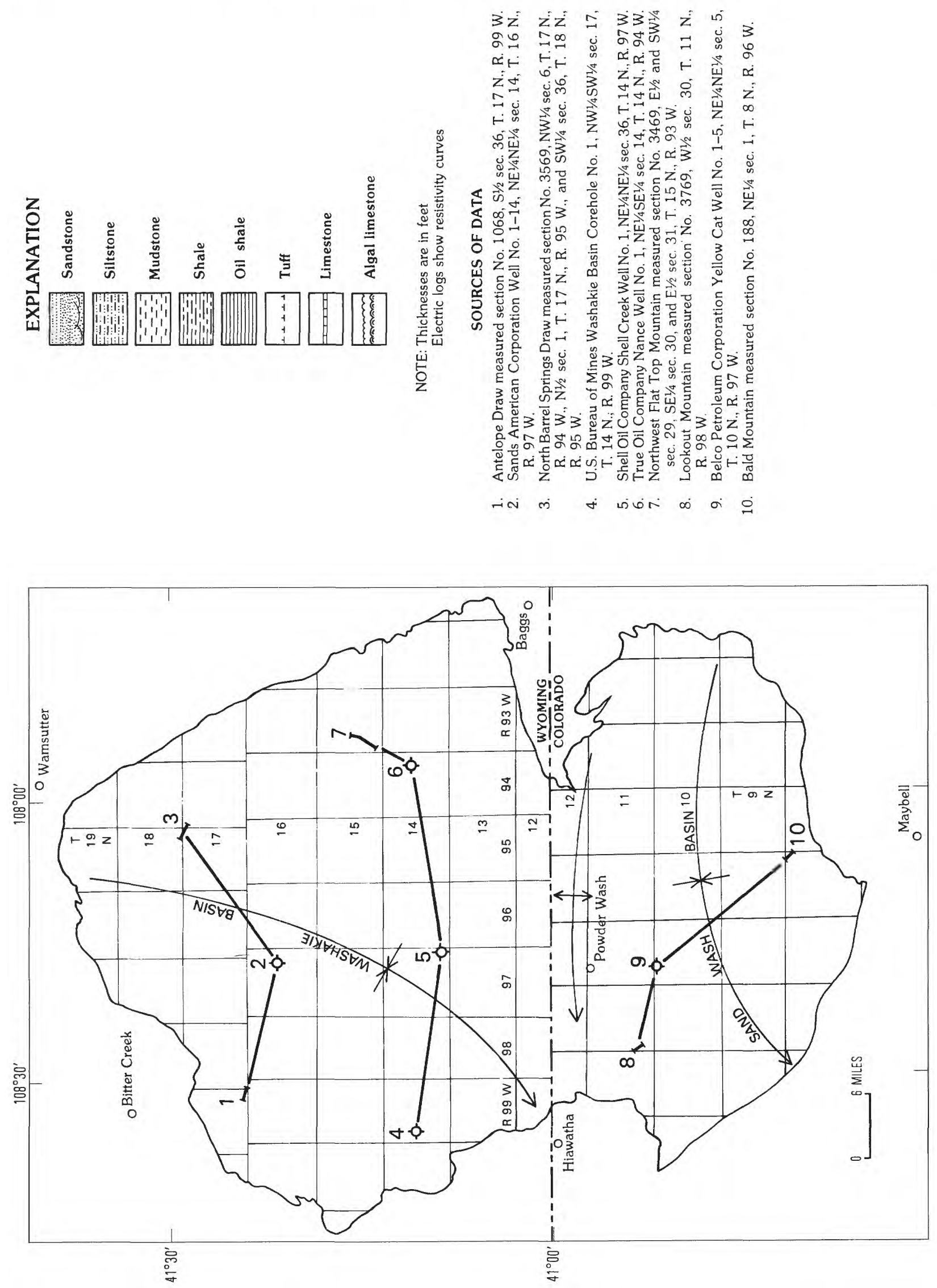


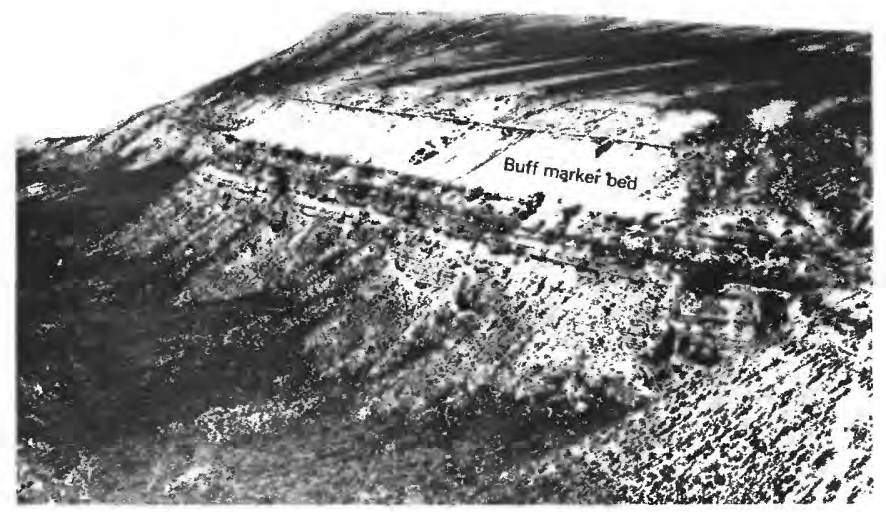

Figure 8.-Outcrops of the buff marker bed and adjacent oil shale beds in the lower part of the LaClede Bed of the Laney Member of the Green River Formation on Kinney Rim in the western Washakie basin in sec. 22 , T. 15 N., R. 100 W. The buff marker bed is $59 \mathrm{ft}$ thick here. Contact of the LaClede Bed with the underlying Cathedral Bluffs tongue of the Wasatch Formation is covered in lower left part of photograph.

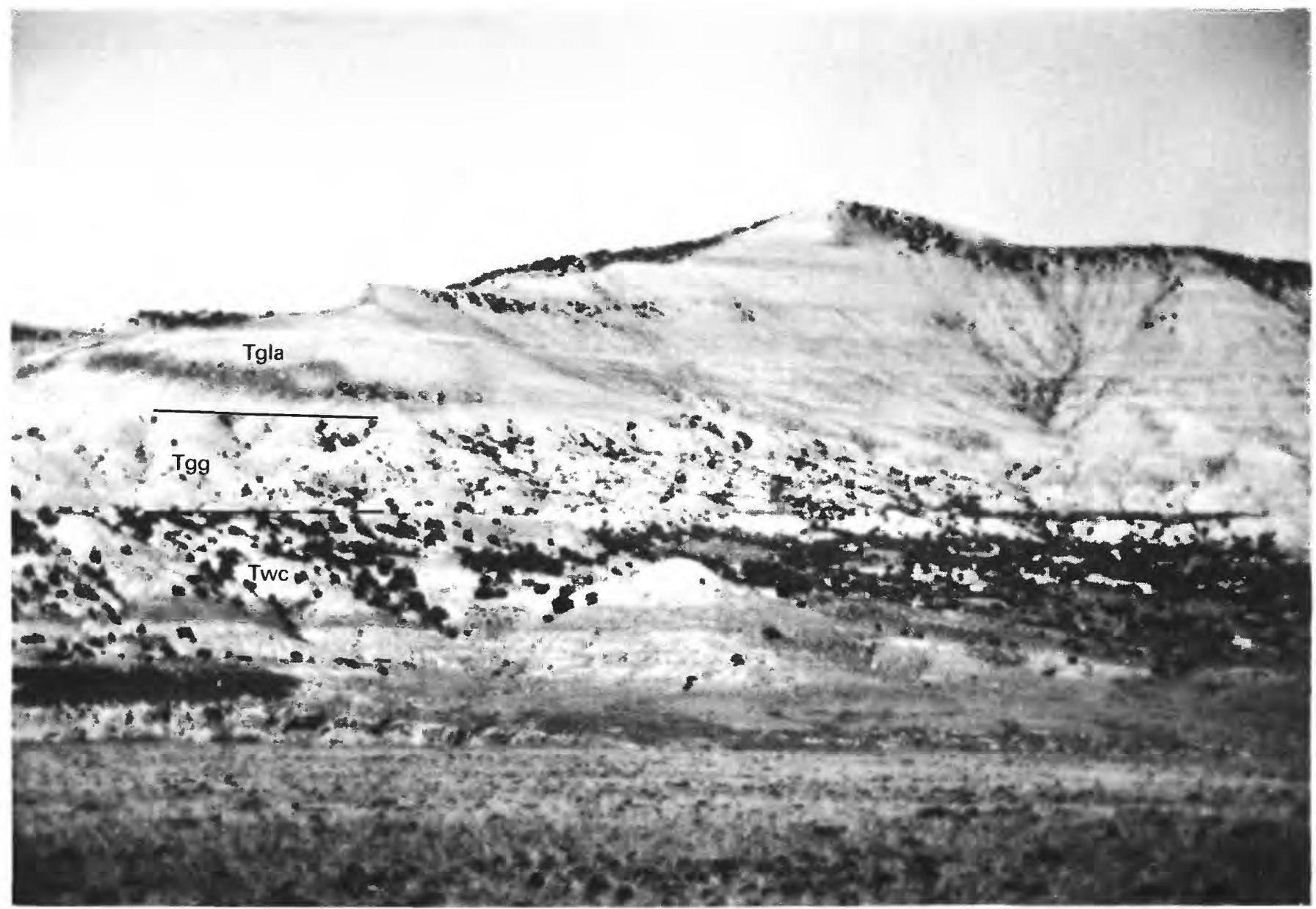

Figure 9.-Outcrops of the LaClede Bed of the Laney Member (Tgla) and Godiva Rim Member (Tgg) of the Green River Formation and the Cathedral Bluffs Tongue (Twc) of the Wasatch Formation, west side of Little Snake River, Sand Wash basin. View is to the west toward The Nipple in T. 10 N., R. 96 W. The Godiva Rim Member is $185 \mathrm{ft}$ thick here. 


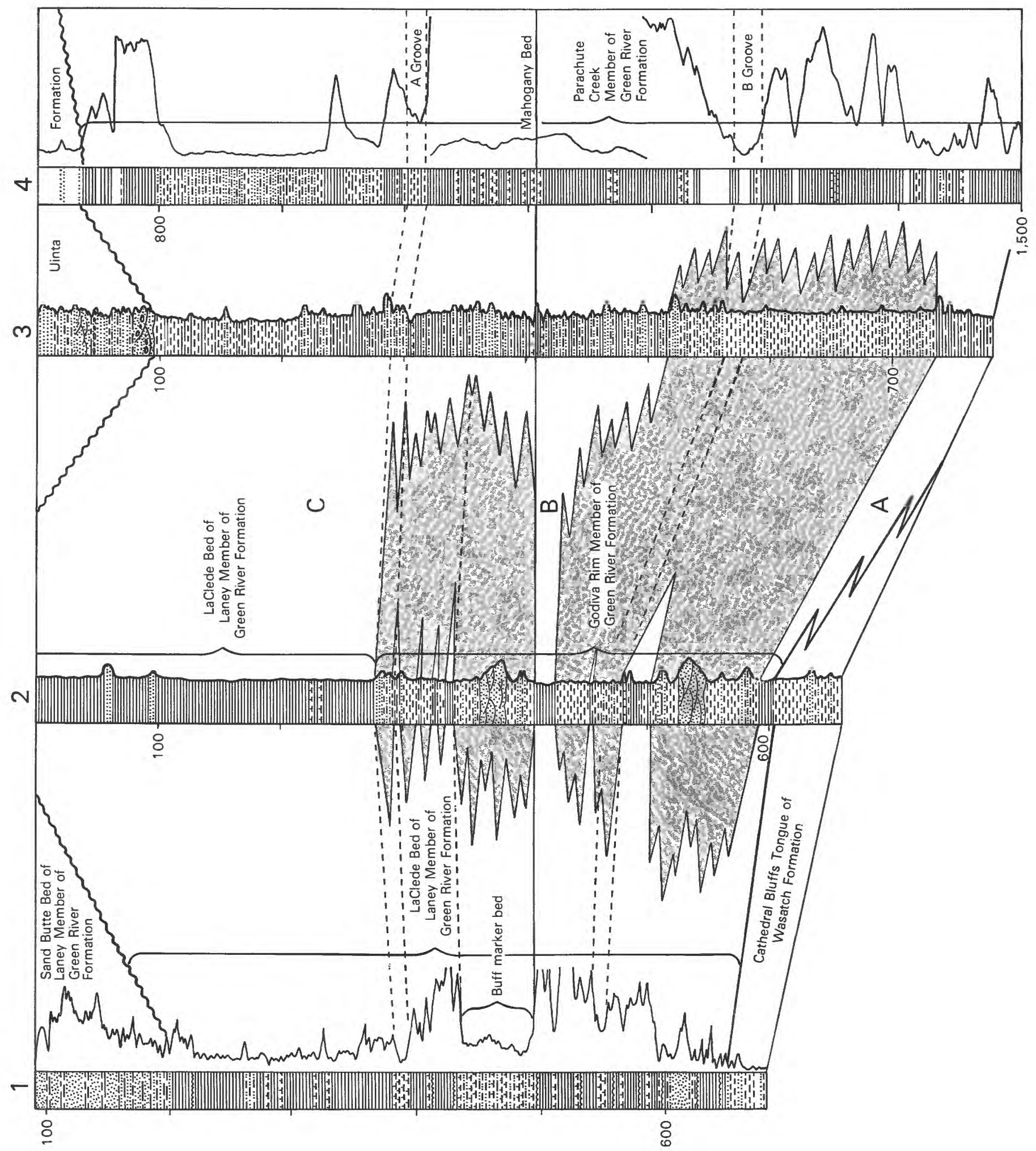




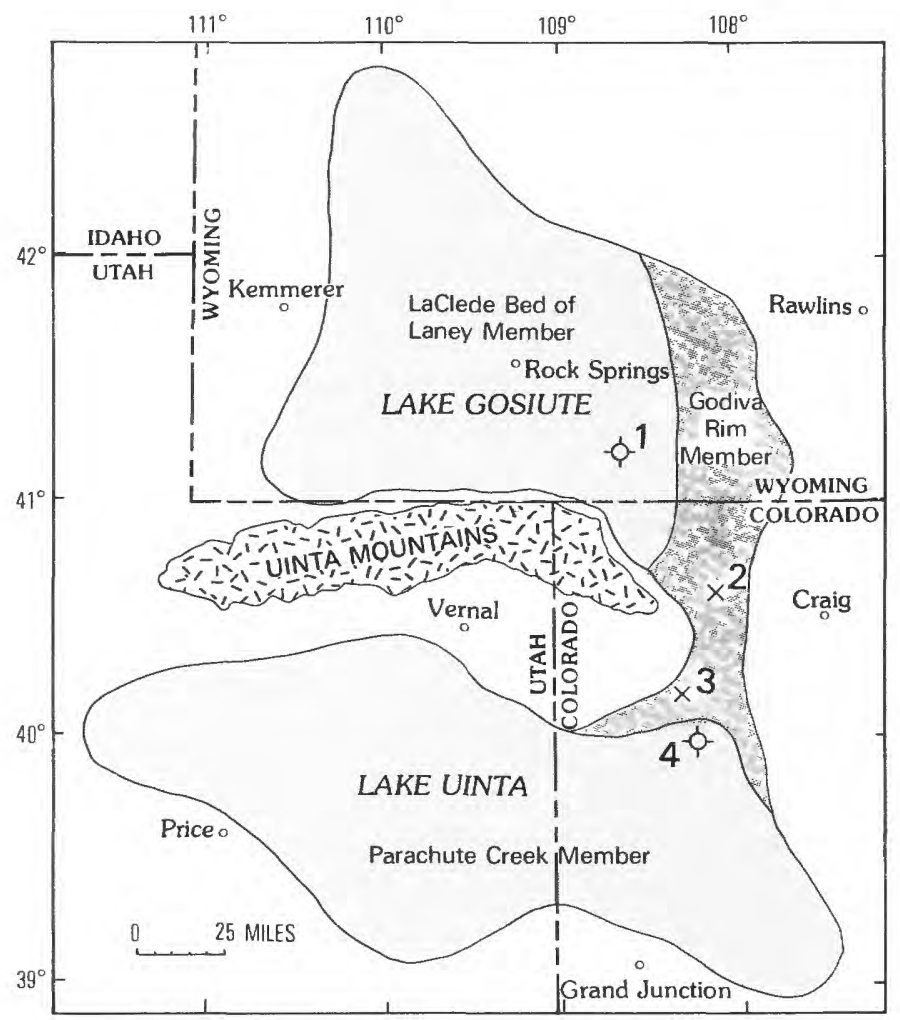

NOTE: Thicknesses are in feet

Electric logs show resistivity curves Lithologies are described in figure 7

\section{SOURCES OF DATA}

1. U.S. Bureau of Mines Washakie Basin Corehole No. 1, sec. 17, T. 14 N., R. 99 W.

2. Bald Mountain measured section No. X88, sec. 1, T. 8 N., R. 96 W.

3. Yellow Creek measured section No. 967 , secs. 9,10 and 15, T. 2 N., R. 98 W.

4. U.S. Bureau of Mines Yellow Creek Corehole No. 1, sec. 13, T. 1 N., R. 98 W.

Figure 10 (above and facing page).-Cross section showing the probable connections of the Eocene Lake Gosiute and Lake Uinta east of the Uinta Mountains. A, B, C, the intervals of the merging open water; intervals of the intervening mudflats are patterned. Generalized paleogeography shown on index map. Datum is the top of the Mahogany Bed. Thicknesses shown are drill-hole depths or measured section intervals. 



\section{SELECTED SERIES OF U.S. GEOLOGICAL SURVEY PUBLICATIONS}

\section{Perlodicais}

Earthquakes \& Volcanoes (issued bimonthly).

Preliminary Determination of Epicenters (issued monthly).

\section{Technical Books and Reports}

Professional Papers are mainly comprehensive scientific reports of wide and lasting interest and importance to professional scientists and engineers. Included are reports on the results of resource studies and of topographic, hydrologic, and geologic investigations. They also include collections of related papers addressing different aspects of a single scientific topic.

Bulletins contain significant data and interpretations that are of lasting scientific interest but are generally more limited in scope or geographic coverage than Professional Papers. They include the results of resource studies and of geologic and topographic investigations; as well as collections of short papers related to a specific topic.

Water-Supply Papers are comprehensive reports that present significant interpretive results of hydrologic investigations of wide interest to professional geologists, hydrologists, and engineers. The series covers investigations in all phases of hydrology, including hydrogeology, availability of water, quality of water, and use of water.

Circulars present administrative information or important scientific information of wide popular interest in a format designed for distribution at no cost to the public. Information is usually of short-term interest.

Water-Resources Investlgations Reports are papers of an interpretive nature made available to the public outside the formal USGS publications series. Copies are reproduced on request unlike formal USGS publications, and they are also available for public inspection at depositories indicated in USGS catalogs.

Open-File Reports include unpublished manuscript reports, maps, and other material that are made available for public consultation at depositories. They are a nonpermanent form of publication that may be cited in other publications as sources of information.

\section{Maps}

Geologic Quadrangle Maps are multicolor geologic maps on topographic bases in 7 1/2-or 15-minute quadrangle formats (scales mainly $1: 24,000$ or $1: 62,500$ ) showing bedrock, surficial, or engineering geology. Maps generally include brief texts; some maps include structure and columnar sections only.

Geophysical Investigations Maps are on topographic or planimetric bases at various scales; they show results of surveys using geophysical techniques, such as gravity, magnetic, seismic, or radioactivity, which reflect subsurface structures that are of economic or geologic significance. Many maps include correlations with the geology.

Miscellaneous Investigations Series Maps are on planimetric or topographic bases of regular and irregular areas at various scales; they present a wide variety of format and subject matter. The series also includes 7 1/2-minute quadrangle photogeologic maps on planimetric bases which show geology as interpreted from aerial photographs. Series also includes maps of Mars and the Moon.
Coal Investigations Maps are geologic maps on topographic or planimetric bases at various scales showing bedrock or surficial geology, stratigraphy, and structural relations in certain coal-resource areas.

Oil and Gas Investigations Charts show stratigraphic information for certain oil and gas fields and other areas having petroleum potential.

Miscellaneous Field Studies Maps are multicolor or black-andwhite maps on topographic or planimetric bases on quadrangle or irregular areas at various scales. Pre-1971 maps show bedrock geology in relation to specific mining or mineral-deposit problems; post-1971 maps are primarily black-and-white maps on various subjects such as environmental studies or wildemess mineral investigations.

Hydrologic Investigations Atiases are multicolored or black-andwhite maps on topographic or planimetric bases presenting a wide range of geohydrologic data of both regular and irregular areas; principal scale is $1: 24,000$ and regional studies are at $1: 250,000$ scale or smaller.

\section{Catalogs}

Permanent catalogs, as well as some others, giving comprehensive listings of U.S. Geological Survey publications are available under the conditions indicated below from the U.S. Geological Survey, Books and Open-File Reports Section, Federal Center, Box 25425, Denver, CO 80225. (See latest Price and Availability List.)

"Publications of the Geological Survey, 1879-1961" may be purchased by mail and over the counter in paperback book form and as a set of microfiche.

"Publications of the Geological Survey, 1962-1970" may be purchased by mail and over the counter in paperback book form and as a set of microfiche.

"Publications of the U.S. Geological Survey, 1971- 1981" may be purchased by mail and over the counter in paperback book form (two volumes, publications listing and index) and as a set of microfiche.

Supplements for 1982,1983, 1984, 1985, 1986, and for subsequent years since the last permanent catalog may be purchased by mail and over the counter in paperback book form.

State catalogs, "List of U.S. Geological Survey Geologic and Water-Supply Reports and Maps For (State)," may be purchased by mail and over the counter in paperback booklet form only

"Price and Avallability List of U.S. Geological Survey Publications," issued annually, is available free of charge in paperback booklet form only.

Selected coples of a monthly catalog "New Publications of the U.S. Geological Survey" available free of charge by mail or may be obtained over the counter in paperback booklet form only. Those wishing a free subscription to the monthly catalog "New Publications of the U.S. Geological Survey" should write to the U.S. Geological Survey, 582 National Center, Reston, VA 22092.

Note.--Prices of Government publications listed in older catalogs, announcements, and publications may be incorrect. Therefore, the prices charged may differ from the prices in catalogs, announcements, and publications. 